\title{
Stability and phenotypic adaptability by AMMI analysis in cowpea beans (Vigna unguiculata (L.) Walp.) ${ }^{1}$
}

\author{
Estabilidade e fenotípica adaptabilidade por análise AMMI em feijão caupi (Vigna \\ unguiculata (L.) Walp.)
}

\author{
Hermes Araméndiz-Tatis ${ }^{2 *}$, Carlos Cardona-Ayala ${ }^{2}$ and Miguel Espitia-Camacho
}

\begin{abstract}
Cowpea beans (Vigna unguiculata (L.) Walp), is the most important legume in the Colombian Caribbean and is cultivated mainly by family-economy farmers under variable environmental conditions. This demands the identification of cultivars with greater adaptation and stability, since genotype - environment interaction (GEI) hinders the process of selection and recommendation of cultivars that, because of their genetic potential, exceed the current yield $\left(600 \mathrm{~kg} \mathrm{ha}^{-1}\right)$. The objective of this study was to evaluate the adaptability and stability of 10 cowpea bean genotypes of semi-prostrate habit in eight environments of the Colombian Caribbean, during the years 2017B and 2018A; using the randomized complete block design with four repetitions. The analysis was performed using the additive main effects and multiplicative interaction (AMMI) model. The results showed highly significant differences at the level of environments, genotypes and GEI. The first three axes of the interaction were significant, selecting the first two for accumulating $81.84 \%$ of the sum of squares of the genotype by environment interaction. Genotype 2 showed the greatest adaptability and stability, but its performance was slightly lower than the average; genotypes 6 and 10 presented the highest grain yields, but were influenced by the environments, with the best response in favorable environments. The best environments corresponded to VN8A and SA7B.
\end{abstract}

Key words: Genotype-environment interaction, Principal component analysis, Semi-prostrate habit, Environments, Genotypes.

\begin{abstract}
RESUMO- O feijão caupi (Vigna unguiculata (L.) Walp), é a leguminosa mais importante do Caribe colombiano e é cultivado principalmente por agricultores familiares em condições ambientais variáveis. Isso exige a identificação de cultivares com maior adaptação e estabilidade, visto que a interação genótipo - ambiente (IGA) dificulta o processo de seleção e recomendação de cultivares que, devido ao seu potencial genético, permitem superar a produtividade atual $\left(600 \mathrm{~kg} \mathrm{ha}^{-1}\right)$. O objetivo deste estudo foi avaliar a adaptabilidade e estabilidade de 10 genótipos de feijão-caupi de hábito semipós-cultivado em oito ambientes do Caribe colombiano, durante os anos 2017B e 2018A; usando o delineamento de blocos completos casualizados com quatro repetições. A análise foi realizada utilizando o modelo de efeitos principais aditivos e interação multiplicativa (AMMI). Os resultados mostraram diferenças altamente significativas ao nível de ambientes, genótipos e IGA. Os três primeiros eixos da interação foram significativos, selecionando os dois primeiros por acumular $81,84 \%$ da soma dos quadrados do genótipo por interação com o ambiente. O genótipo 2 apresentou maior adaptabilidade e estabilidade, mas seu desempenho foi ligeiramente inferior à média; os genótipos 6 e 10 apresentaram os maiores rendimentos de grãos, mas foram influenciados pelos ambientes, com melhor resposta em ambientes favoráveis. Os melhores ambientes corresponderam a VN8A e SA7B.
\end{abstract}

Palavras-chave: Interação genótipo-ambiente Análise de componentes principais. Hábito semiprostrado. Ambientes. Genótipos.

DOI: $10.5935 / 1806-6690.20210032$

Editor-in-Chief: Prof, Alek Sandro Dutra - alekdutra@ufc.br

*Author for correspondence

Received for publication on 13/04/2020; approved on 10/08/2020

${ }^{1}$ This article is a product of the Research Project Funded by Colciencias, Universidad de Córdoba and Fundación Canal del Dique de Compas

${ }^{2}$ University of Córdoba, Department of Agronomic Engineering and Rural Development, Montería-Córdoba-Colombia, haramendiz@correo. unicordoba.edu.co (ORCID ID 0000-0002-2585-6273), cecardona@correo.unicordoba.edu.co(ORCID ID 0000-0002-9607-3858),mmespitia@ correo.unicordoba.edu.co (ORCID ID 0000-0001-7382-9643) 


\section{INTRODUCTION}

Cowpea beans are the most important legume in the Colombian Caribbean, cultivated by small producers with Creole cultivars, which show low yield $\left(600 \mathrm{~kg} \mathrm{ha}^{-1}\right)$ due to the use of non-certified seeds and susceptibility to abiotic factors such as drought, temperature, and biotics such as bacteria, weeds, insects, and fungi (PATRIYAWATY; RACHAPUTI; GEORGE, 2018; SINDHU et al., 2019).

Among the species cultivated in semi-arid tropical and subtropical areas, cowpea beans stand out (KIRIGIA et al, 2018), with phenotypic plasticity which allows it to adapt to drought and high temperatures, to guarantee grain production, although not all cultivars respond in the same way (ALVES-BARROS et al., 2013; EL-SHAIENY et al.,2015). It is sensitive to drought stress, especially in the flowering period (GULL; SOFI; ARA, 2019), affecting yield components (MEENA; RAM-KRISHNA; SINGH, 2015), which could be aggravated by the omens of the effects of climate change and climate variability on agriculture (IPCC, 2014). In this sense, studies carried out by Singh et al. (2010), in cowpea beans, showed that the interaction between $\mathrm{CO}_{2}$, temperature and ultra violet rays differentially affect cultivars, especially in the reproductive stage, with reduction in the number of fruiting branches, pollen viability and, consequently, the yield, which depends on the time of stress (SAGE et al., 2015).

Yield is a characteristic of polygenic nature affected by the environment, which makes genetic improvement difficult (WALLE et al., 2019); in this sense, cowpea beans are cultivated in Colombia, in areas that show a wide variety of environmental conditions associated with the hydric state of the soil, fertility, solar radiation, temperature, types of soil and production technologies; that cause differential phenotypic values of the genotypes according to the environmental supply, a phenomenon called genotype-by-environment interaction (OLIVEIRA et al., 2017; SÁNCHEZ-RAMÍREZ; MENDOZACASTILLO; MENDOZA-MENDOZA, 2016).

For genetic improvement programs in their final phase, the evaluation of promising genotypes under heterogeneous environmental conditions of the producing areas (localities and years) where the crops are established is of great relevance. With this type of evaluation, the phenotypic expression of the plant in various environmental conditions is better understood, since the presence of genotype-by-environment interaction makes the selection process difficult due to the sensitivity of the plants to the growing conditions (VAEZI et al., 2019). Analysis of the interaction of genotypes with environments is effective in characterizing the response of genotypes in the various environments and allows the selection of those with wide adaptation and stability (LIGARRETO M.; CASTRO H.;
CHÁVES C., 2015; TOSQUY-VALLE et al., 2019).

Various methods have been carried out in cowpea in order to release cultivars, among them, the AMMI (additive main effects and multiplicative interaction) model, which is multivariate and appropriate for analyzing two-dimensional matrices, such as those containing genotype and environmental data (EL-SHAIENY et al., 2015; MONDO; KIMANI; NARLA, 2019; TOSQUYVALLE et al., 2019). The AMMI statistics presented in biplots can be used to provide insightful interpretation of data from large and complex experiments (EBDON; GAUCH JR, 2002).

The objective of this study was to evaluate the adaptability and stability of cowpea bean genotypes of semi-prostrate habit, under environmental conditions of the Caribbean region of Colombia.

\section{MATERIAL AND METHODS}

The grain yield of nine advanced lines of the genetic breeding program of the University of Córdoba, together with the commercial control Caupicor 50, was evaluated in eight environments of the Caribbean region of Colombia in 2017-2018, characterized by being contrasting in their fertility, precipitation and temperatures (Table 1). These materials are characterized by their semi-prostrate growth habit and creamcolored seeds with black hilium. The agronomic evaluation of the genotypes was carried out under an experimental design in randomized complete blocks with 10 treatments and four repetitions per environment. Each experimental unit consisted of six rows of five meters long with $0,80 \mathrm{~m}$ between rows and $0,40 \mathrm{~m}$ between plants for a density of 31,250 plants per hectare. The two central rows were considered as a useful plot and, to avoid the edge effect, two additional rows of the commercial cultivar were placed at the ends. The grain yield data, in $\mathrm{kg} / \mathrm{ha}$, were corrected for $13 \%$ humidity and analyzed using statistical models for analysis of variance (MARTÍNEZ BECERRA; MARTÍNEZ RUEDA, 1997).

The Caribbean region of Colombia has a typical tropical savanna climate subtype Aw, according to the Köppen classification, with a temperature variation between 24 and $28{ }^{\circ} \mathrm{C}$ and annual rainfall between 800 and $1800 \mathrm{~mm}$. This region has soils that differ from one area to another with fertility that varies from high to very low, depending on precipitation and the influence or not of rivers and tributaries. In general, for agricultural activities, two large sub-regions with specific variations in precipitation and soils have been identified: The Dry Caribbean, with higher temperatures and less precipitation, and the Humid Caribbean, with lower temperatures, greater precipitation and soil fertility.

The statistical model for the combined analysis of the localities is: 
Table 1 - Cowpea bean genotypes evaluated in eight environments of the Colombian Caribbean

\begin{tabular}{lccc}
\hline Genotype & Origin $\dagger$ & Environments* & Subregion \\
\hline LC-029-016 & IT86 x LCPM-35 & Leticia - Bolívar: LE8A & Humid C. \\
LC-002-016 & IT86 x LCPM-35 & Mahates-Bolívar: MA7B & Humid C. \\
LC-036-016 & IT86 x LCPM-35 & Montería - Córdoba: MO7B & Humid C. \\
LC-009-021 & IT86 x LCPM-35 & Polonuevo-Atlántico: PN7B & Dry C. \\
LC-029-016 & IT86 x LCPM-35 & Polonuevo - Atlántico: PN8A & Dry C. \\
L-019 & Criollo Córdoba & Sampués-Sucre: SA7B & Humid C. \\
LC-006-016 & IT86 x LCPM-35 & Sampués-Sucre: SA8A & Humid C. \\
LC-005-016 & IT86 x LCPM-35 & Villanueva - Guajira: VN8A & Dry C. \\
\hline LC-014-016 & IT86 x LCPM-35 & & \\
\hline Caupicor 50 & Commercial Cultivar & & \\
\hline : Individual selection method; *: Municipalities of the Colombian Caribbean, second half of 2017 and first half of 2018. Humid Caribbean: Humid C.; \\
Dry Caribbean: Dry C
\end{tabular}

$\mathrm{Y}_{\mathrm{ijk}}=\mu+\pi_{\mathrm{i}}+\rho_{\mathrm{ij}}+\tau_{\mathrm{k}}+(\pi l)_{i k}+\varepsilon_{\mathrm{ijk}}$

$i=1,2, \ldots, 1 ; j=1,2, \ldots, r ; k=1,2, \ldots, t$

Where: $\mathrm{Y}_{\mathrm{ijk}}$ : response or characteristic under study; $\mu$ : general mean; $\pi_{i}$ : effect of the $\mathrm{i}$-th locality; $\rho_{\mathrm{i}}$ : effect of the $\mathrm{j}$-th block within the $\mathrm{i}$-th location; $\tau_{\mathrm{k}}$ : effect of the k-th treatment; $(\pi l)_{i k}$ : effect of the interaction of the i-th location and the k-th treatment; $\varepsilon_{\mathrm{ijk}}$ : is the experimental error in the i-th location, in the j-th block under the k-th treatment. Both the analysis of variance by environment and the combined one of the localities were processed with SAS software, version 9.4.

The effect of the genotype-environment interaction (GEI) was analyzed by means of the AMMI (additive main effects and multiplicative interaction) model. This model combines the analysis of variance for the principal effects of genotypes and environments with the analysis of principal components for GEI. The AMMI model considers that the effects of genotypes and environments are additive and linear, while the GEI has multiplicative effects that can be studied by principal component analysis (EBDON; GAUCH JR, 2002). A detailed description of the fixed effects model for AMMI (ZOBEL; WRIGHT; GAUCH JR, 1988) has the following structure:

$\mathrm{Y}_{\text {ger }}=\mu+\alpha_{g}+\beta_{e}+\sum_{n=1}^{N} \lambda_{n} \zeta_{g n} n_{e n}+\varepsilon_{\text {ger }}$

Where: $\mathrm{Y}_{\text {ger }}$ : performance of genotype $\mathrm{g}$ in environment $\mathrm{e}$ for repetition $\mathrm{r}$; $\mu$ : general mean; $\alpha_{\mathrm{g}}$ : effect of genotype $\mathrm{g}$ : mean deviation of the genotype (mean minus the general mean); $\beta_{\mathrm{e}}$ : effect of the environment; e: mean deviation of the environment; $\mathrm{N}$ : number of axes in the principal component analysis (PCA) retained in the model; $\lambda_{\mathrm{n}}$ : square root of the eigenvalue for the n-axis of the PCA; $\varsigma_{\mathrm{gn}}$ and $\eta_{\mathrm{en}}$ : PCA scores for their own axes $\varepsilon_{\text {ger }}$ : error of model.
The eigenvectors (scores) in the PCA for genotypes and environments are dimensionless, while the units for the eigenvalues, $\lambda$, have the same units as the response variable (EBDON; GAUCH JR, 2002; ZOBEL, 1988). The software GEA-R (Genotype $\times$ Environment Analysis with $\mathrm{R}$ for Windows) Version 4.1 was used for AMMI analysis; in the International Maize and Wheat Improvement Center CIMMYT (PACHECO et al., 2017).

The objective of this study was to evaluate the adaptability and stability of cowpea bean genotypes of semi-prostrate habit, under the environmental conditions of the Caribbean region of Colombia.

\section{RESULT AND DISCUSSION}

The combined analysis of variance estimated significant differences between genotypes, between environments and in the genotype x environment interaction (Table 2), indicates that the grain yield of cowpea varies according to the environments, and is consistent with the results of Alves-Barros et al. (2013), and El-Shaieny et al. (2015). The existence of this significant interaction leads to studying the stability and adaptability of the genotypes in the various environments.

Table 3 shows the results of the estimates of the mean squares for the main additive effects and genotype environment interaction (GEI) for the grain yield between environments and genotypes, with statistical evidence of the variability between environments and between genotypes. The existence of GEI is based on the genetic differences between genotypes and environmental factors such as fertility, precipitation and temperature between the 
Table 2- Analysis of variance for grain yield of 10 cowpea bean genotypes in eight environments of the Caribbean Region of Colombia 2017-2018

\begin{tabular}{lccc}
\hline Sources of variation & Degrees of freedom & Mean squares & Pr $>$ F \\
\hline Environment (E) & 7 & $8563295.5^{* *}$ & $<0.0001$ \\
Block (Environments) & 24 & $101754.2^{* *}$ & 0.0026 \\
Genotype (G) & 9 & $1115131.3^{* *}$ & $<0.0001$ \\
G x E & 63 & $214723.14^{* *}$ & $<0.0001$ \\
Error & 216 & 47988.2 & \\
Mean & $1,134.8$ & & \\
\hline CV (\%) & 19.30 & & \\
\hline R2 & 0.89 & & \\
\hline
\end{tabular}

humid and the dry Caribbean (GULL; SOFI; ARA, 2019; SINDHU et al., 2019; SINGH et al., 2010), which justifies carrying out a study of genotypes to know the magnitudes of their interaction with environments (OLIVEIRA et al., 2017; SÁNCHEZ-RAMÍREZ; MENDOZACASTILLO; MENDOZA-MENDOZA, 2016), since it affects the correlation and reliability between phenotypic and genotypic values and makes it difficult to select and recommend superior cultivars (LIGARRETO M.; CASTRO H.; CHÁVES C., 2015; VAEZI et al., 2019).

In the breakdown of total variation in treatments, it was observed that environmental effects were responsible for the greatest variation with a value of $71.78 \%$, followed by GEI with $16.19 \%$ and finally, the contribution of genetic differences in cultivars with $12.01 \%$. This is consistent with Mondo, Kimani and Narla (2019) and Vaezi et al. (2019), who argued that this occurs due to the strong interaction between years and localities, in which the stresses caused by abiotic factors, especially in the dry Caribbean localities, mainly affect the number of pods per plant and number of seeds per pod (WALLE et al., 2019). In addition, high temperatures in the reproductive stage affect pollen production and viability (PATRIYAWATY; RACHAPUTI; GEORGE, 2018), since temperatures are higher in the dry Caribbean relative to the humid Caribbean.

According to the Gollob test (1968), in the AMMI analysis, the mean squares of the GEI show that the first two components $\mathrm{PC} 1$ and $\mathrm{PC} 2$ account for $81.84 \%$ of the variation (Sum of Squaree of the GEI interaction) and $44.44 \%$ of the degrees of freedom, while the first three PC1, PC2 and PC3, accounted for $93.34 \%$ and $61.90 \%$, respectively. The rest of the principal components were not significant (Table 3 ). The explanation of GEI, in a little more than $80 \%$ of the variation, with the first two components is satisfactory to understand the interaction between genotypes and environments (LIGARRETO M.; CASTRO H.; CHÁVES C., 2015; TOSQUY-VALLE et al., 2019).
The GEI residual made up of PC4 to PC7 (Table 3) represents a mean square (MS) of 37,552.68 with 24 degrees of freedom (df) not significant with an $\mathrm{F}$ of only 0.70 . Furthermore, if a GEI residual made up of PC3 to PC7 is considered, it will still be insignificant, since the resulting MS is 70,198.06 with $35 \mathrm{df}$ for a F-value of 1.32. The partitioning of the sum of squares (SS) by the AMMI model was quite effective, given that the mean square of the first axis of the PCA is more than 14 times the MS of the estimated residual of the interaction from $\mathrm{PC} 4$ to $\mathrm{PC} 7$, and 13 times the estimate from PC3 to PC7. On the other hand, the AMMI model without the error term contains $98.92 \%$ of the SS and the residual of the interaction was $1.08 \%$ when the grouping to estimate the GEI residual was made from the fourth principal component to the last. When the grouping was done from the third principal component, 97.06 and 2.94\% were obtained, respectively.

In either of the two cases, the GEI residual indicates that the model to be interpreted is the AMMI2 and the variation present in the rest of the principal components is negligible and makes noise, which may reduce the efficiency of interpretation of the stability of the genotypes and the environment in the graphic analysis according to what was reported by Mondo, Kimani and Narla (2019) in common beans; Sánchez-Ramírez, Mendoza-Castillo and MendozaMendoza (2016) in corn and Tadesse et al. (2017) in bean.

For the analysis of stability, the first step consisted in estimating the existence of significant differences between the yields of the genotypes in the evaluated environments. Subsequently, the sources of variation were broken down (Table 3 ) to estimate the effects of GEI on principal components to continue with the study of adaptability and stability.

Figure 1 presents the biplot in which the abscissa shows the principal effects (means of the genotypes and environments) and the ordinate the first axis of the PCA. Therefore, this AMMI1 has $59.97 \%$ of the total 
Table 3. Mean squares of the additive main effects and multiplicative interaction through the Analysis of variance and Gollob test of the AMMI Model of 10 cowpea bean genotypes evaluated in eight environments of the Colombian Caribbean 2017-2018

\begin{tabular}{lccccc}
\hline SV & DF & MS & $\%$ SS & \%SS $_{\text {GXA }}$ & Prob. F \\
\hline Environment (E) & 7 & $8563295.50^{* *}$ & 71.78 & & 0.00000 \\
Genotype (G) & 9 & $1115131.34^{* *}$ & 12.02 & & 0.00000 \\
G x E & 63 & $214723.14^{* *}$ & 16.20 & & 0.00000 \\
PC1 & 15 & 540815.30 & $59.97^{* *}$ & 59.97 & 0.00000 \\
PC2 & 13 & 227568.95 & $21.87^{* *}$ & 81.84 & 0.00000 \\
PC3 & 11 & 141424.35 & $11.50^{* *}$ & 93.34 & 0.00322 \\
PC4 & 9 & 42390.73 & 2.82 & 96.16 & 0.62169 \\
PC5 & 7 & 48247.18 & 2.50 & 98.65 & 0.50378 \\
PC6 & 5 & 32514.95 & 1.20 & 99.86 & 0.69278 \\
PC7 & 3 & 6480.93 & 0.14 & 100.00 & 0.94739 \\
PC8 & 0 & 0.00 & 0.00 & 100.00 & 1.00000 \\
\hline Residual & 240 & 53364.79 & & & \\
\hline
\end{tabular}

$\mathrm{SV}=$ source of variation; $\mathrm{DF}=$ degrees of freedom; $\mathrm{MS}=$ mean squares; $\% \mathrm{SS}=$ percentage of the total sum of squares; $\% \mathrm{SS}_{\mathrm{GXA}}=$ percentage of the sum of squares of the genotype - environment interaction; $\mathrm{G} x \mathrm{E}=$ genotype by environment interaction; PC1, PC2, .., PC $8=$ principal component 1 , $2, \ldots, 8$, respectively; $* *=$ significant with $\mathrm{P} \leq 0.01$

sum of squares (SS) of the GEI and $93,52 \%$ of the SS of the reduced AMMI model, without the error term. Furthermore, the GEI is shown in a uni-dimensional way (GAUCH JR; PIEPHO; ANNICCHIARICO, 2008). Given the dispersion of genotypes and environments, it was observed that GEI is appreciable, which is due to the genetic complexity of performance (MONDO; KIMANI; NARLA, 2019; SÁNCHEZ-RAMÍREZ; MENDOZACASTILLO; MENDOZA-MENDOZA, 2016), as well as environmental divergence in the Caribbean region of Colombia. Hence the differential response of genotypes in different environments, is due to the magnitude of their contribution to genotype - environment interaction (ELSHAIENY et al., 2015).

In general, genotypes 1,2, 7,8 and 9 have small effects on interaction, that is, they are little affected by environments, while genotypes 3, 4, 5, 6 and 10 have high effects on interaction with environments, with instability in yield.

Genotypes 8 and 9 showed above average yield and were slightly affected by environment, in contrast genotypes 6 with specific adaptability for VN8A and 10 showed the highest yields, but were significantly affected by environments. These two genotypes responded positively to the extent that the environment was favorable. Similar results were reported by Ligarreto M., Castro H. and Cháves C. (2015) for common beans, which could be associated with the influence of yield components such as the number of pods per plant, number of seeds per pod and weight of 100 seeds (MEENA; RAMKRISHNA; SINGH, 2015; MENDONÇA et al., 2018). On
Figure 1. Biplot analysis for grain yield $\left(\mathrm{kg} \mathrm{ha}^{-1}\right)$ of 10 cowpea cultivars evaluated in eight environments of the Colombian Caribbean. 1= LC-029-016; 2=LC-002-016; 3=LC-036-016; 4=LC-009-016; 5=LC-021-016; 6=L-019; 7=LC-006-016; $8=\mathrm{LC}-005-016 ; 9=\mathrm{LC}-014-016 ; 10=$ Caupicor $50 ; 1=\mathrm{LE} 8 \mathrm{~A}$; 2=MA7B; 3=MO7B; 4=PN7B; 5=PN8A 2018; 6=SA7B; $7=\mathrm{SA} 8 \mathrm{~A} ; 8=\mathrm{VN} 8 \mathrm{~A}$

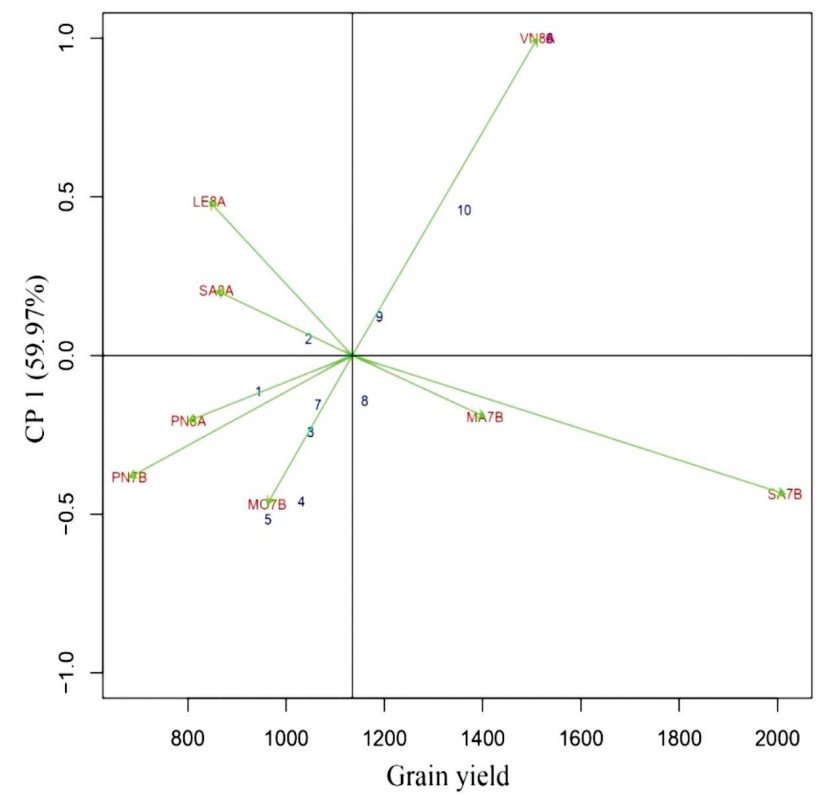

the other hand, genotypes 4 and 5 had a yield below the general mean (Figure 1) and are also affected by different environments. 
At the level of environments, MA7B, VN8A and $\mathrm{SA7B}$, turned out to be the most favorable, as the 10 genotypes showed average values above $1,400 \mathrm{~kg} \mathrm{ha}^{-1}$, while PN7B was the least favorable with an average of $700 \mathrm{~kg} \mathrm{ha}^{-1}$ (Table 4).

The AMMI2 analysis combined the first two principal components of the GEI, which added up to $81.84 \%$ of the SS of the GEI and $97.06 \%$ of the SS of the reduced AMMI model, without the error term (Figure 2). In the biplot of the AMMI2 analysis, the SA8A environment is the closest to the origin and contributed the most to the phenotypic stability of the genotypes. However, it was in this environment that the second lowest yield was recorded, $850 \mathrm{~kg} \mathrm{ha}^{-1}$. On the other hand, the VN8A, SA7A and LE8A environments, those furthest from the origin of Figure 1, contributed more to the GEI, that is, to the instability of the genotypes (Table 4); the results were concordant with those reported in common beans by Mondo, Kimani and Narla (2019).
Genotypes close to the environments were positively associated: genotype 2 showed adaptation to all environments, it showed the greatest phenotypic stability, although its average yield was barely $1,045 \mathrm{~kg} / \mathrm{ha}$; genotype 3 adapted to $50 \%$ of the environments: PN7B, PN8A, MA7B and MO7A, with an average yield of $1,050 \mathrm{~kg} \mathrm{ha}^{-1}$; genotypes 1 and 8 , with yields of 944 and $1,159 \mathrm{~kg} \mathrm{ha}^{-1}$, showed adaptation to the SA7B environment; genotype 5 showed very good adaptation to the PN7B environment and its average yield was $963 \mathrm{~kg} \mathrm{ha}^{-1}$; genotype 10 adapted to the VN8A and SA8A environments and its average yield was $1,362 \mathrm{~kg} \mathrm{ha}^{-1}$; genotype 4 showed adaptation to PN8A and PN7B environments; 7 to MA7B; genotypes 6 and 10 were the most unstable, although the first registered the highest yield, $1,536 \mathrm{~kg} \mathrm{ha}^{-1}$ (Table 4).

For commercial recommendation purposes, genotypes must present both agronomic characteristics and excellent yields, such is the case of genotype 6 , which outperformed the rest, including the commercial control genotype 10 .

Table 4 - Averages of genotypes and environments for grain yield $\left(\mathrm{kg} \mathrm{ha}^{-1}\right)$ of cowpea by the additive main effects and multiplicative interaction (AMMI) model, plus scores of the first three axes of the principal component analysis, for 10 semi-prostrate cultivars in eight Colombian Caribbean environments 2017-2018

\begin{tabular}{lccccc}
\hline Factor & ID & Yield & PC1 & PC2 & PC3 \\
\hline GEN & 1 & 944.0 & -0.1133 & -0.3685 & -0.2489 \\
GEN & 10 & 1362.1 & 0.4584 & -0.1055 & -0.1115 \\
GEN & 2 & 1045.6 & 0.0531 & 0.1077 & -0.1317 \\
GEN & 3 & 1050.1 & -0.2422 & 0.1296 & 0.3453 \\
GEN & 4 & 1031.3 & -0.4607 & 0.2078 & 0.2451 \\
GEN & 5 & 963.2 & -0.5175 & -0.0113 & 0.3236 \\
GEN & 6 & 1536.9 & 1.0000 & 0.2477 & 0.3186 \\
GEN & 7 & 1064.8 & -0.1562 & 0.6498 & -0.5463 \\
GEN & 8 & 1159.6 & -0.1429 & -0.3026 & -0.0512 \\
GEN & 9 & 1190.0 & 0.1214 & -0.5547 & -0.1430 \\
Environment & LE8A & 844.0 & 0.4857 & 0.4767 & 0.2326 \\
Environment & MA7B & 1404.8 & -0.1934 & 0.4343 & -0.2642 \\
Environment & MO7B & 961.6 & -0.4690 & -0.1942 & 0.2778 \\
Environment & PN7B & 681.1 & -0.3844 & -0.0254 & -0.4579 \\
Environment & PN8A & 801.3 & -0.2064 & 0.2969 & -0.1838 \\
Environment & SA7B & 2015.6 & -0.4369 & -0.6144 & 0.1511 \\
Environment & SA8A & 858.3 & 0.2045 & 0.1024 & 0.5357 \\
Environment & VN8A & 1511.4 & 1.0000 & -0.4764 & -0.2913 \\
\hline
\end{tabular}

ID: Identification of genotype and environment. GEN (genotype): 1. LC-02916; 2. LC-002-016; 3. LC-036-016; 4. LC-009-016; 5. LC-021-016; 6. L-019; 7. LC-006-016;8. LC-005-016; 9. L-014-016; 10. CAUPICOR 50. Environment: LE8A (Leticia 2018A); MA7B (Mahates 2017B); MO7B (Montería 2017B); PN7B (Polonuevo 2017B); PN8A (Polonuevo 2018A); SA7B (Sampués 2017B); SA8A (Sampués 2018A); VN8A (Villanueva 2018A) 
Figure 2. Biplot analysis concerning the graphic representation of $\mathrm{PC} 1$ and $\mathrm{PC} 2$, allusive to the genotype-by-environment interaction for 10 cowpea bean cultivars evaluated in eight environments of the Colombian Caribbean. 1= LC-029-016; 2=LC-002-016; 3=LC-036-016; 4=LC-009-016; 5=LC-021016; 6=L-019; 7=LC-006-016; 8=LC-005-016; 9=LC-014-016; $10=$ Caupicor $50 ; 1=\mathrm{LE} 8 \mathrm{~A} ; 2=\mathrm{MA} 7 \mathrm{~B} ; 3=\mathrm{MO} 7 \mathrm{~B} ; 4=\mathrm{PN} 7 \mathrm{~B}$; 5=PN8A 2018; 6=SA7B; 7=SA8A; 8=VN8A.

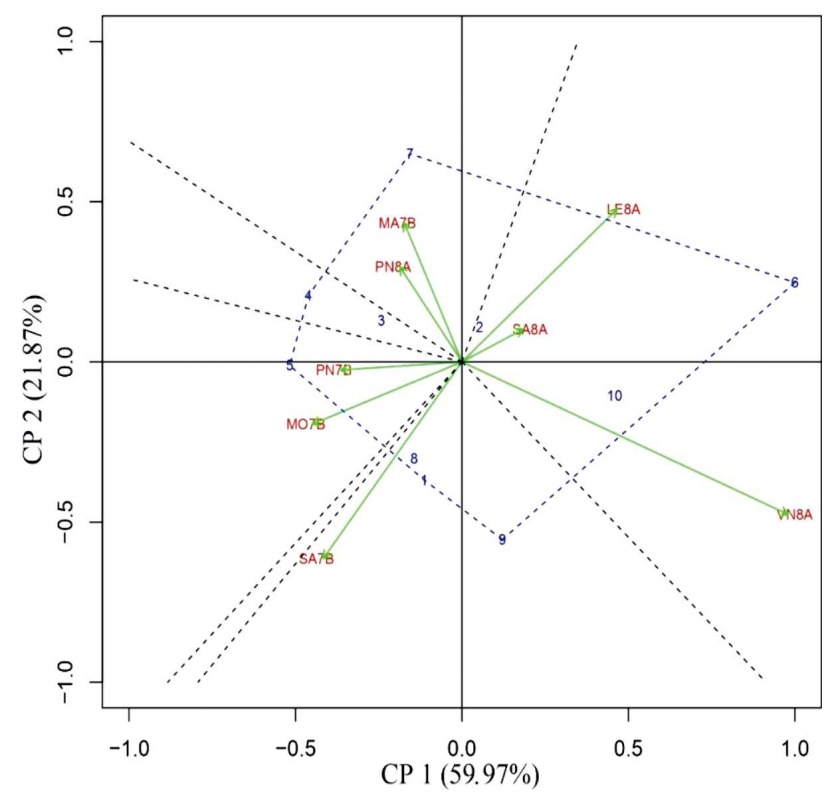

\section{CONCLUSIONS}

1. Environmental effects were mainly responsible for the variation detected in the study, highlighting PN7B as the least favorable environment and VN8A and $\mathrm{SA} 7 \mathrm{~B}$, as the most favorable for cowpea bean production;

2. Genotypes 6 and 10 showed the highest grain yields, but were influenced by the environments, with higher yield in favorable environments;

3. Genotype 2 showed greater stability and adaptability in the studied environments, with a yield below the average.

\section{ACKNOWLEDGEMENT}

The authors express their gratitude to Colciencias, the Universidad de Córdoba and the Fundación Promotora del Canal del Dique, for financing the research project on cowpea beans.

\section{REFERENCES}

ALVES-BARROS, M.etal. Adaptabilidadee estabilidadeprodutiva de feijão caupide porte semiprostrado. Pesquisa Agropecuaria Brasileira, v. 48, n. 4, p. 403-410, 2013.

EBDON, J.S.; GAUCH JR, H. G. Additive main and multiplicative interaction analysis of national turfgrass performance trials: I. Interpretation of genotype $\mathrm{x}$ environment interaction. Crop Science, v. 42, n. 2, p. 489-496, 2002.

EL-SHAIENY, A.A.H. et al. Stability analysis of components characters in cowpea (Vigna unguiculata (L.) Walp). Journal of Horticulture and Forestry, v. 7, n. 2, p. 24-35, 2015

GAUCH JR, H.G.; PIEPHO, H.P.; ANNICCHIARICO, P. Statistical analysis of yield trials by AMMI and GGE: further considerations. Crop Science, v. 48, n. 3, p.866-889, 2008.

GOLLOB. H. F. A statistical model which combines features of factor analytic and analysis of variance techniques. Psychometrika, v. 33, n.1, p.73-115, 1968.

GULL, M.; SOFI, P.A.; ARA, A. Physiological and biochemical response of cowpea (Vigna unguiculata L.) landraces of Kashmir valley under water stress. ElectronicJournalof Plant Breeding, v. 10, n. 4, p. 1461-147, 2019.

IPCC. Grupo Intergubernamental de Expertos sobre el Cambio Climático. Cambio climático 2014:impactos, adaptación y vulnerabilidad. Resúmenes, preguntas frecuentes y recuadros multicapítulos. Contribución del Grupo de trabajo II al Quinto Informe de Evaluación del Grupo Intergubernamental de Expertos sobre el Cambio Climático. Editado por Christopher B. Field et al. Ginebra: Organización Meteorológica Mundial, 2014. 200 p.

KIRIGIA, D.et al. Development stage, storage temperature and storage duration influence phytonutrient content in cowpea (Vigna unguiculata L. Walp.). Heliyon, v. 4, n. 6, p. e00656, 2018.

LigarRetO M., G.A.; CASTRO H., O.A.; CHÁVES C., B. Estabilidad fenotípica de una colección de fríjol andino (Phaseolus vulgaris L.) tipo arbustivo. Revista U.D.C.A Actualidad \& Divulgación Científica, v. 18, n.1, p. 109-118, 2015.

MARTÍNEZ BECERRA, R.; MARTÍNEZ RUEDA, N. Diseño de experimentos: análisis de datos estándar y no-estándar. Santafé de Bogotá: Fondo Nacional Universitario, 1997. 479 p.

MEENA, H.K.; RAM-KRISHNA, K.; SINGH, B. Character associations between seed yield and its components traits in cowpea [Vigna unguiculata (L.) Walp.]. Indian Journal of Agricultural Research, v.49, n.6, p. 567-570, 2015.

MENDONÇA, M.et al. Importance and correlations of characters for cowpea diversity in traditional varieties. Revista Ciência Agronômica, v. 49, n. 2, p. 267-274, 2018.

MONDO, J.M.; KIMANI, P.M.; NARLA, R.D. Genotype x environment interactions on seed yield of inter-racial common bean lines in Kenya. World Journal of Agricultural Research, v. 7, n.3, p.76-87, 2019. 
OLIVEIRA, D.S.V. et al. Adaptability and tability of the zinc density in cowpea genotypes through GGE-Biplot method. Revista Ciência Agronômica, v. 48,n. 5, p. 783-791, 2017. Número especial.

PACHECO, Á.et al."GEA-R (Genotype $\mathbf{x}$ Environment Analysis with R for Windows) Version 4.1". hdl:11529/10203. CIMMYT Research Data \& Software Repository Network, V16, 2017. Disponível em: https://data.cimmyt.org/dataset.xhtml?per sistentId=hdl:11529/10203.Acessoem: 30 abril de 2020 .

PATRIYAWATY， N.R.; RACHAPUTI，R.C.N.; GEORGE, D. Physiological mechanisms underpinning tolerance to high temperature stress during reproductive phase in mungbean (Vigna radiata (L.) Wilczek). Enviromental and Experimental Botany, v. 150, p.188-197, 2018.

SAGE, T.L.et al. The effect of high temperature stress on male and female reproduction in plants. Field CropsResearch, v. 182 , p. 30-42, 2015

SÁNCHEZ-RAMÍREZ，F.; MENDOZA-CASTILLO, M.C.; MENDOZA-MENDOZA, C.G. Estabilidad fenotípica de cruzas simples e híbridos comerciales de maíz (Zea mays L.). Revista Fitotecnia Mexicana, v. 9, n.3, p.269-275, 2016.

SINDHU, M. et al. Current advances and future directions in genetic enhancement of a climate resilient food legume crop, cowpea (Vigna unguiculata L. Walp.). Plant Cell, Tissue and Organ Culture, v. 139, n. 3, p. 429-453, 2019.

SINGH, S.K.et al. Cowpea (Vigna unguiculata (L.) Walp) genotypes response to multiple abiotic stresses. Journal of Photochemistry and Photobiology B: Biology, v.100, n. 2, p.135-146, 2010

TADESSE, T.et al. Genotypes by environment interaction of Faba Bean (Vicia faba L.) Grain Yield in the Highland of Bale Zone, Southeastern Ethiopia. Plant, v. 5, n.1, p.13-17, 2017.

TOSQUY-VALLE, O.H. et al. Adaptación de genotipos de frijol negro a diferentes ambientes de Veracruz y Chiapas. Revista Mexicana de Ciencias Agrícolas, v.10, n. 6, p.1301-1312, 2019.

VAEZI, B.et al. Integrating different stability models to investigate genotype environment interactions and identify stable and high-yielding barley genotypes. Euphytica, v. 215, n. 4 , p. $63,2019$.

WALLE, T. et al. Correlation and path coefficient analyses of cowpea (Vigna unguiculata L.) landraces in Ethiopia. American Journal of Plant Sciences, v. 9, n. 13, p. 2794-2812, 2019.

ZOBEL, R.; WRIGHT, M.; GAUCH JR, H. G. Statistical analysis of a yield trial. AgronomyJournal, v. 80, n. 3, p. 388-393, 1988. 